\title{
The Role of Psychological Empowerment and Organizational Citizenship Behaviors on Employee Resistance to Change
}

\author{
Asli Goksoy \\ The American University in Bulgaria
}

\begin{abstract}
In today's competitive business world, change is inevitable for organizations. During an organizational change, the toughest challenge of organizational leaders is to manage employee resistance to change. It is well established in literature that employee resistance is one of the leading causes for the failure of organizational change efforts. The purpose of this paper is to explore the impact of psychological empowerment and organizational citizenship behaviors on employee resistance to change. It also investigates if psychological empowerment can be used as a human resource management strategy during a planned change in order to increase commitment to change. The study took place in Turkey in a private company which went under a strategic organizational change recently. Survey collection from employees and interviews with two human resource managers were the main tools in collecting information. The results from 85 respondents showed that both psychological empowerment and organizational citizenship behaviors have significant negative influence on employee resistance to change. The interview results showed that through psychological empowerment, employees were more involved in change process, took active role in decision making and were more committed to the change. The implications of the study can be used by organizational change practitioners to maintain employees' positive reactions to change by considering psychological empowerment and organizational citizenship behaviors as a tool to lower the level of resistance.
\end{abstract}

Keywords: Psychological empowerment, organizational citizenship behaviors, employee resistance to change, commitment to change

\section{Introduction}

Organizational change has been a major business trend in today's business environment. Change is a need, in some cases a must for an organization. It is complex, challenging and requires intensive effort and time. The main goal to change is to make the organization more effective and efficient in performance and increase its competitive advantage. A great deal of articles and books have been written about change management to provide the answer to successful organizational change. However, organizational change is an extremely difficult in practice, as over 70 percent of organizational change efforts either fail or underperform (Burke, 2011; Cinite et al., 2009). There are many reasons why organizational change efforts do not reach their objectives, but employee resistance is often cited as one of the most leading causes for the failure of change initiatives (Bovey \& Hede, 2001). In a study of 288 companies who shared lessons and best practices in change management, Creasey found that the top obstacle to change was employee resistance at all levels (Haslam \& Pennington, 2004).

Resistance is expected in change management. There is a human tendency to resist change, because it forces people to adopt new ways of doing. Resistance is a natural response to a perceived threat of personal loss. The most common beliefs about resistance are that it is harmful, as it introduces costs and delays into the change process (Ansoff, 1990), and cause lowered morale and disruptive work environment. Employees' resistance is destructive, as it has significant negative effect on essential work behaviors such as employees' organizational commitment, job-satisfaction and positive relationship with intention to leave their organizations (Oreg, 2006).

Resistance to change is critical barrier to the success of the changes; however, with proper change management and leadership, resistance to change can be minimized, even avoided. This can be achieved by engaging employees in the early stage of change process. Capturing and leveraging the passion and positive emotion surrounding a change can many 
times prevent resistance from occurring (prosci. com). This can be achieved through employee empowerment and organizational citizenship behavior.

Psychological empowerment refers to a set of psychological states that are necessary for employees to feel a sense of control in relation to their work. It is mainly about how employees experience their work and their role in relation to the organization (Spreitzer, 2007). Empowerment is a management strategy that has been touted by practitioners and researchers as one of the answers that organizations need to meet the challenges of the current business environment, especially in the context of turbulent and dynamic changes. Empowered people are motivated by knowing that they possess the power to produce changes or have the ability to influence the environment within which they are embedded (Chan, 2003). Empowered employees can change the organization to a learning one in such a way that it increases its capabilities continuously and achieve its desired results.

Organizational citizenship behavior is another antecedent that has impact on resistance, as it expresses employee loyalty and identification with organizational goals (Chahal \& Mehta, 2010). Additionally, organizational citizenship behavior is another concept which organizations require to survive in the challenging and competitive environment of the contemporary age. If employees work in their own organization as good organizational citizens, they can help their organization to be more competitive and change it into an ambiance full of trust and motivation (Bagheri, Matin \& Amighi, 2011). As working under changing circumstances becomes an essential feature of organizations (Lee, Dendrick, \& Smith, 1991), organizations will necessarily become more dependent on individuals who are willing to contribute to successful change, regardless of formal job requirements (Somech \& Drach-Zahavy, 2004: 281). Behaviors that exceed delineated role expectations, but are important and even crucial for an organization's survival are defined as organizational citizenship behaviors (Brief \& Motowidlo, 1986; George, 1990).

In this research, the impact of psychological empowerment and organizational citizenship behavior on employee resistance to change is investigated. This study is important, because the need to understand the effect of resistance has increased significantly in private industries and government organizations over the last decade because of globalization, fast-changing markets and economic developments (Piderit, 2000). Additionally, while much attention has been given to such perspectives and how to overcome resistance to change, the role that positive employees may play in positive organizational change has been largely ignored (Avey \& Wernsing, 2008). Therefore, any study that evaluates resistance may provide an important point of reference to understand the variables that support organizational change and it will help change agents and practitioners to create the appropriate interventions to minimize employees' resistance.

\section{Literature review}

\section{Employee resistance to change}

Resistance to change is defined as the pattern of organizational behavior that decision makers in organization employ to actively deny, reject and refuse to implement, repress or even dismantle change proposals and initiative. Resistance is the resultant employee's reaction of opposition to organizational change (Folger \& Skarlicki 1999). Resistance can be attitudinal and behavioral responses to change. Attitudinal resistance to change would entail a psychological rejection of the need for the change, whereas behavioral resistance would be represented by behaviors that reflect an unwillingness to support the change or unwillingness to stay with the organization through this tumultuous time (i. e. lack of commitment to change) (Chawla \& Kelloway, 2004).

In literature, there are many different factors that have been commonly identified as causes of resistance to change. Change starts with the perception of its need so a wrong initial perception is the first barrier to change (Pardo Del Val \& Fuentez, 2003) such as inability of the company to look into the future with clarity and denial or refusal to accept any information that is not expected or desired (Kriger, 1996), communication barriers, that lead to information distortion or misinterpretations (Hutt, Walker \& Frankwick, 1995). Other reasons may be listed as a low motivation for change (Pardo Del Val \& Fuentez, 2003), mistrust of management, a fear of failure/unknown, loss of status or job insecurity, and peer pressure (Kreitner \& Kinicki, 2004)

An overview of the literature reveals that resistance to change has more negative consequences than positive ones for employees and organization. It is a key variable affecting change decisions and outcomes and also it might lead to a failure of organizational change (Regar et al., 1994). Resistance can lead to dysfunctional behavior, such as withdrawal (Abramson et al., 1978), decrements in performance (Bazerman, 1982), and acting out (Galphin, 1996). Resistant behaviors, 
employees can engage in a work slowdown, loose of loyalty to the organization and motivation to work. The number of absenteeism, errors and mistakes increase (Robbins, 2003). A recent study also found that resistance to change was related to lower levels of job satisfaction and intentions to quit (Wanberg \& Banas, 2000). Resistance often results in politics or political behavior (Kotter \& Schlesinger, 1989).

\section{Commitment to change}

Employee commitment to change is extremely important for an organization that is embarking on a change program (Michaelis et al., 2010). Herscovitch \& Meyer (2002) define commitment to change as a force (mind-set) that binds an individual to a course of action deemed necessary for the successful implementation of a change initiative. Employees with a high commitment to change are not passive, but active in implementing the change program (Fedor et al., 2006). Commitment to change shows that people may have various motivations to support a change (Herscovitch \& Meyer, 2002). Some employees are committed to their organization because they love what they do, or because the organizational goals are in the same line with their own goals. Other employees might be afraid of the things they lose when they quit working or feel obligated to the organization, or to their manager. In the three-component model of commitment (Meyer \& Allen, 1991) are three components of commitment distinguished: affective commitment, continuance commitment, and normative commitment.

It can be predicted that there is a strong correlation between psychological empowerment and commitment to change. Study done by Malik et al. (2013), Hashmi and Naqvi (2012), Ambad (2012), Dehkordi et al. (2011) have stated that psychological empowerment has correlated with organizational commitment. Based on the findings from Rashid and Zhao (2010), and Mangundjaya (2013) showed that organizational commitment had positive and significant correlation with commitment to change. It can be assumed that psychological empowerment has positive and significant correlation with commitment to change.

\section{Organizational citizenship behavior (OCB)}

OCB refers to "those organizationally beneficial behaviors and gestures that can neither be enforced on the basis of formal role obligations nor elicited by contractual guarantee of recompense" (Izhar, 2009). Organ (1988) defines OCBs as "individual behavior that is discretionary, not directly or explicitly recognized by the formal reward system, and that in the aggregate promotes the effective functioning of the organization. OCBs have 5 dimensions. Altruism is mainly about helping behaviors which is advantageous for the organization (Organ et al., 2006). Conscientiousness consists of behaviors that go well beyond the minimum role requirements of the organization (Law, Wong \& Chen, 2005). These behaviors indicate that employees accept and adhere to the rules, regulations, and procedures of the organization. Civic virtue can be demonstrated on a larger scale by defending the organization's policies and practices when they are challenged by an outside source. Courtesy is about preventing problems from arising. Finally, sportsmanship is defined as a willingness on the part of the employees that signifies the employee's tolerance of less than ideal organizational circumstances without complaining and blowing problems out of proportion. More importantly, it is the ability to roll with the punches even if they do not like or agree with the changes that are occurring within the organization.

In an organizational change context, OCB can act like an informal psychological contract for instance through sportsmanship by demonstrating tolerance of less than ideal circumstances without complaining (Omer \& Umut, 2007) in most case, change is considered as unexpected or less preferable and also through civic virtue by participating in organizational practices with the concern of the life of the company such as change. In change process, employees with high OCBs will be willing to follow the rules, and directions of change agents, more collaborative and less conflict oriented. Based on Chernyak-Hai and Tziner's findings (2012) OCB remained the only significant predictor of openness to organizational change which indicates willingness to support change and positive affect about its possible consequences (Wanberg \& Banas, 2000). Therefore, the following hypothesis is derived:

Hypothesis 1: OCB is negative related to employee resistance to change.

\section{Psychological empowerment}

Psychological empowerment is about psychological states that produce perception of empowerment in the workplace (Rahman, Panatik \& Alias, 2014). Researchers, such as Yukl and Becker (2006) and Conger and Kanungo (1988), have defined psychological empowerment as workers' influence in decision making processes that are most commonly 
associated with four factors: meaningfulness, competence, choice, and impact. These factors may help make workers feel more motivated and in control of their workplace environment. Empowerment offers the potential to positively influence outcomes that benefit both individuals and organizations (Liden \& Tewksbury, 1995).

It has four dimensions. Meaning involves a fit between the needs of one's work role and one's beliefs, values and behaviors (Hackman \& Oldham, 1980). Competence (self-efficacy) is an individual's belief in his or her capability to perform task activities skillfully. Self-determination is a sense or autonomy of choice in initiating and regulating one's actions. Impact is the degree to which an employee can influence strategic, administrative, or operating outcomes at work (Spreitzer, 2007).

Empowerment is an important construct in change management. In the literature of change management and resistance, the proposed ways by different authors for overcoming resistance to change are collectively expressed in different words like participation and empowerment (Kotter \& Schlesinger 1979; Mabin \& Forgeson 2001; Chawla \& Kelloway, 2004). Psychological empowerment management practices represent an important contextual buffer against the negative effects of dispositional resistance to change. Psychological empowerment (Spreitzer, 1995) is important concept to consider when dealing with changes at work and improving performance. Psychological empowerment increases employees' sense of personal control and motivates them to engage in work, which in turn results in positive managerial and organizational outcomes (Quinn \& Spreitzer, 1997). Main reasons for resistance are feeling excluded from the process and lack of competence. By psychological empowerment, employees are allowed to be part of the change, and they can influence the outcome. Psychological empowerment can enhance employees' decision making in change process by giving them increased participation, authority, freedom and information. Lastly, psychological empowerment translates into increased productivity and efficiency, increasing their ability to adapt to change and be more responsive to transforming workplace issues (Lin \& Tseng, 2013). In summary, this research proposes the following hypothesis:

Hypothesis 2: Psychological empowerment is negative related to employee resistance to change.

\section{Methodology}

\section{Participants}

With convenience sampling method, participants completed the study's instruments on a voluntary basis. The participants who volunteered to take part in the study were 85 employees ( 47 men, 38 women; mean age $=37.68$ ) in a private company in Istanbul. They had a mean of 13. 5 years of work experience and 7.3 years at their existing organization. $60 \%$ of the participants ( $N=51$ ) had managerial duties, whereas $40 \%(\mathrm{~N}=34)$ did not have a managerial duty basically working at the clerical level. They all have bachelor's degree; 54 employees also have a master degree.

\section{Instrument}

The questionnaire used in this study was 3 pages long and included three sections. Section one was the cover page explaining the purpose and the nature of the study. Section two included demographic questions such as age, gender, tenure track, and position. Section three included 52 questions of measures of psychological empowerment and organizational citizenship behaviors and employee resistance to change. All questions were translated into Turkish for semantic and syntactic equivalence by two research associates. Resistance to change was measured by Oreg (2003) 16item scale. The 16 items cover four dimensions: routine seeking, emotional reaction, short-term thinking and cognitive rigidity. The Cronbach's alpha reliability was 0.85 . The response scale ranged from 1 (strongly disagree)-7 (strongly agree). Spreitzer (1995) 12-item scale was used to measure psychological empowerment. The measure comprises four dimensions: competence, meaning, self-determination and impact. The Cronbach's alpha reliability was 0.93 . Responses ranged from 1 (completely disagree)-5 (completely agree). To measure employees' OCB Organ's questionnaire (1988) was used. Twenty-four items were used based on five main dimensions (altruism, courtesy, conscientiousness, sportsmanship, and civic virtue). The Cronbach's alpha reliability was 0.87 . The response scale ranged from 1 (strongly disagree)-7 (strongly agree).

\section{Findings and Results}

To test the impacts of model variables, factors were computed and the reliability analyses were done to all of the factors by SPSS 21. 0 version. In order to determine the factor structures of variables, the principal components analysis, method of factor analysis with Varimax rotation was used. Each step was conducted on one- item- a time basis by discarding any item with a factor loading of less than. 50, or which loaded to more than one factor with a. 10 or less difference, or that 
singly loaded on a factor. Those factors with Eigenvalues of 1.00 or more were taken into consideration in total variance explained. The internal consistencies of the scales were calculated by Cronbach's Alpha and the factors with Alpha values of. 70 were considered to have sufficient reliability.

The analysis starts with designating the descriptive statistics for demographics in order to provide an overall picture of the sample. Table 1 includes descriptive statistics of the participants.

Table 1. Sample Characteristics of Participants

\begin{tabular}{llll} 
Variable & Group & $\mathrm{N}$ & Percentage \\
\hline Age & up to 30 years & 12 & 14.1 \\
& 31 to 40 years & 48 & 56.5 \\
& 41 to 50 years & 20 & 23.5 \\
& 51 to 60 years & 5 & 5.9 \\
\hline Gender & male & 47 & 55.3 \\
& female & 38 & 44.7 \\
\hline Overall work experience & up to 10 years & 26 & 30.6 \\
& 11 to 21 years & 45 & 52.9 \\
& 21 and up & 14 & 16.5 \\
\hline Job position & non managerial & 34 & 40 \\
& mid-level management & 32 & 37.6 \\
& senior level management & 19 & 22.4 \\
\hline
\end{tabular}

To test Hypothesis 1, a simple regression analysis was conducted to examine the contribution psychological empowerment to employee resistance to change. The results showed there is significant negative relationship between these two variables $(\beta=-.39, p=.001)$. To test Hypothesis 2, a simple regression analysis was conducted to examine the contribution organizational citizenship behaviors to employee resistance to change. The results showed there is significant negative relationship between these two variables $(\beta=-.34, p=.000)$.

In order to investigate the impact of psychological empowerment as a human resource management strategy during a planned strategic change to increase commitment to change, two interviews were made with human resource division managers separately. 12 questions were asked in total. The answers were based on managers' perception about employees' commitment, as there was no quantitative information about this variable. Based on the answers, the findings were: psychological empowerment gave freedom to employees to be a part of change process. Empowered employees feel a strong sense of ownership for the planned change. Employees felt powerful and confident in decision making especially when the decisions were about their daily task and routines part of change plans. Managers used open communication channels to receive feedback from their employees on a regular base and evaluated the impact of psychological empowerment. Compared with previous experiences, managers believed that employees felt less stressed, more motivated, as employees did not felt like they were forced to change.

\section{Conclusion}

Today's fast-moving environment requires organizations to undergo changes almost constantly (Jones \& Brazzel, 2006; Kotter, 2010). Managers and change agents want these changes to succeed and therefore, do anything in their power to achieve this goal. By implementing a change, no matter what size it is, every organization should expect to meet some level of resistance from employees. To reduce this resistance and the negative reactions from within the organization, it is useful and more importantly a need for organizations to know more about the reasons why employees resist. Because of that, the topic of change and resistance is well acknowledged in the literature and is one of the great themes in the social sciences (e. g. Cummings \& Worley, 2014; Thompson, 2011).

Organizational scholars and practitioners alike have argued that if organizations are to flourish in the volatile global environment and meet the concomitant challenges of geographic dispersion, electronic collaboration, and cultural diversity, they must become more knowledge intensive, decentralized, participative, adaptive, flexible, efficient and responsive to rapid change. Muir (2014) found that this can be achieved through methods of increasing employee participation and empowering more employees to make decisions. The involvement and participation increase ownership and commitment 
to change, and fosters the work environment in which employees are motivated and contributing. It is well established in literature that one of the ways to reduce resistance is to build positive and trustworthy relationship with employees to increase commitment. This can be also reached by psychological empowerment.

Widespread interest in psychological empowerment comes at a time when global competition and change require employee initiative and innovation (Drucker, 1988). Despite of cultural and organizational differences, previous research which found that individual factors specifically employee empowerment support individual readiness for change. (Rafferty \& Simmons, 2006; Lam, Cho \& Qu, 2007). In this study, it was found that the employees with psychological empowerment show less resistance to change. Empowerment increases employees' participation level in the decision making process, which means encouraging employees to participate more actively in the change. In summary, there is consensus among academics that to introduce change successfully, managers often need to gain the support of employees. To do so, they are advised to use practices that empower employees (Tesluk, Vance, \& Mathieu, 1999; Morgan \& Zeffane, 2003).

Today, changes in organizational environments, their resultant innovations, and flexibility are emphasized, which necessarily calls for voluntary behavior from members of an organization. Accordingly, an organization should be capable of shifting its members' attitudes and behaviors which act for organizational development from egoistic behaviors. With regard to this issue, many researchers have paid attention to organizational citizenship behavior (Lee, Kim \& Kim, 2013). In this study, it was found that employees with organizational citizenship behavior show less resistance, but more commitment. This can be explained in an organizational content as commitment can be seen an employee's attachment to the change program (Ford et al., 2003). This kind of commitment has strong relationship with organizational citizenship behavior (Fedor et al., 2006).

Employee commitment to a change process is of paramount importance for changes to be effective. Lau and Woodman (1995) conceptualized commitment to change as a "specific attitude towards change". The interview results in this study showed that through psychological empowerment, employees were more involved in change process, took active role in decision making and were more committed to the change. Psychological empowerment gives employees desire to support change initiatives and sense of obligation to be supportive of the organization's plans for change, therefore it is essential for HR managers consider psychological empowerment as a tool to increase commitment and also lower the resistance. Based on this findings organizations undergo any change process need to pay attention on this matter.

\section{References}

[1] Abramson, L. Y., M. E. P. Seligman and J. D. Teasdale. (1978). Learned helplessness in humans: critique and reformulation. Journal of Abnormal Psychology. 87, 49-74.

[2] Ambad, S. N. A. \& Bahron, A. (2012). Psychological Empowerment: The Influence on Organizational Commitment among Employees in the Construction Sector, The Journal of Global Business Management, 8 (2), 73-81.

[3] Ansoff, I. H. (1990), Implanting Strategic Management, Prentice Hall International, Ltd. London.

[4] Avey, J. B., Patera, J. L., \& West, B. J. (2006). Positive psychological capital: A new approach for understanding absenteeism. Journal of Leadership and Organizational Studies, 13, 42-60.

[5] Bagheri, G. Matin, H. Z. \& Amighi, F. (2011). The relationship between empowerment and organizational citizenship behavior of the edagogical organization employees. Iranian Journal of Management Studies, 4(2), 53-62.

[6] Bazerman, M. H. (1982). Impact of personal control on performance: Is added control always beneficial? Journal of Applied Psychology, 67, 472-479.

[7] Bovey, W., \& Hede, A. (2001). Resistance to organizational change: The role of cognitive and affective processes. Journal of Managerial Psychology, 16(7), 534-548.

[8] Brief, A. P. \& Motowidlo, S. J. (1986). Prosocial organizational behaviors. Academy of Management Review, 11, 710725 .

[9] Burke, W. W. (2011). A perspective on the field of organization development and change: the Zeigarnik effect. Journal of Applied Behavioral Science, 47(2): 143-167. 
[10] Chan, Y. H. (2003). A nomological network approach to the study of antecedents, moderator, mediators and outcomes of psychological empowerment., Dissertation, The University of Memphis.

[11] Chahal, H., \& Mehta, S. (2010). Antecedents and consequences of organizational citizenship behavior (OCB): A conceptual framework in reference to health care sector. Journal Services Research, 10(2), 366-388.

[12] Chawla, A. \& Kelloway, E. K. (2004). Predicting Openness and Commitment to Change. Leadership \& Organization Development Journal. 25. 5/6; 485.

[13] Chernyak-Hai, L. \& Tziner, A. (2012). Organizational citizenship behaviors: Socio-psychological antecedents and consequences. Revue internationale de psychologie sociale 3 (25), 53-92.

[14] Cinite I, Duxbury LE \& Higgins C (2009) Measurement of perceived organizational readiness for change in the public sector. British Journal of Management, 20(2): 265- 277.

[15] Conger, J. A., \& Kanungo, R. N. (1988). The empowerment process: Integrating theory and practice. Academy of Management Review, 13,471-482.

[16] Cummings, T., \& Worley, C. (2014). Organization development and change. Stamford, CT: Cengage Learning. 42(2), $81-91$.

[17] Dehkordi, L. F., Kamrani, M. N., Ardestani, H. A., \& Abdolmanafi, S. (2011). Correlation Between Psychological Empowerment with Job Satisfaction and Organizational Commitment, Interdisciplinary Journal of Contemporary Research in Business, 3 (7), 808-822.

[18] Drucker, P. (1988). The coming of the new organization. Harvard Business Review, 66: 45-53.

[19] Pedor, D. B., Caldwell, S., \& Herold, D. M. (2006). The effects of organizational changes on employee commitment: a multilevel investigation. Personnel Psychology, 59(1), 1-29.

[20] Folger, R. \& Skarlicki, L. A. (1999). Unfairness and Resistance to Change: Hardship as Mistreatment, Journal of Organizational Change Management. 12(1), 35- 50.

[21] Ford, J. IC, Weissbein, D. A., \& Plamondon, ICE. (2003). Distinguishing organizational from strategy commitment: linking officers' commitment to community policing to job behaviors and satisfaction. Justice Quarterly, 20,159-185.

[22] Galpin, T. J. (1996). The human side of change. San Francisco: Jossey-Bass.

[23] Hackman, J. R., \& Oldham, G. R. 1980. Work redesign. Reading, MA: Addison-Wesley. Haslam, S. \& Pennington, R. (2004). Reducing resistance to change and conflict: A Key to Successful Leadership Resource International, 3-9.

[24] Hashmi, M. S. (2012). Psychological empowerment to boost organizational commitment, evidence from banking sector of Pakistan, International Journal of Human Resource Studies, 2 (2), 132-141.

[25] Herscovitch, L., \& Meyer, J. P. (2002). Commitment to organizational change: Extension of a three-component model. Journal of Applied Psychology, 87(3), 474-487.

[26] Hutt, M. D., B. A. Walker and G. L. Frankwick. (1995). Hurdle the Cross Functional Barriers to Strategic Change. Sloan Management Review. 36, 3, 22-30.

[27] Izhar, O. (2009). Organizational citizenship behavior in teaching: The consequences for teachers, pupils, and the school, International Journal of Educational, 23, 375-389.

[28] Jones, B. B., Brazzel, M., \& NTL Institute for Applied Behavioral Science. (2006). The NTL handbook of organization development and change: Principles, practices, and perspectives. San Francisco, CA: Pfeiffer.

[29] Kinicki, A. \& Kreitner R. (2004). Organizational Behavior. [University of Phoenix Custom Edition e-text]. New York, NY: McGraw-Hill.

[30] Lam, T., Cho, V., \& Qu, H. (2007). A study of hotel employee behavioral intention toward adaptation of information technology. Hospitality Management, 26, 49-65. 
[31] Lee, U. H. Kim, H. K. \& Kim, Y. H (2013). Determinants of Organizational Citizenship Behavior and Its Outcomes. Global Business and Management Research: An International Journal, 5(1), 54-65.

[32] Lee, V., Dedrick, R. \& Smith, J. (1991). The effect of the social organization of schools on teachers' efficacy and satisfaction. Sociology of Education, 64(3), 190.

[33] Kotter, J. P. (2010). Power and influence. Simon and Schuster. New York: Free press.

[34] Kotter, J. P. \& L. A. Schlesinger (1979) Choosing strategies for change. Harvard Business Review, 57, 106-115.

[35] Kriger, W. (1996). Implementation: The core task of change management. CEMS Business Review. 1, 77-96.

[36] Lau, C. M., \& Woodman, R. W. (1995). Understanding organizational change: A schematic perspective. Academy of Management Journal, 38(2), 537-554.

[37] Liden, R. C., \& Tewksbury, T. W. (1995). Empowerment and work teams. In G. R. Ferris, S. D. Rosen, \& D. T. Barnum (Eds. ), Handbook of human Resources Management, 86-403. Oxford, England: Blackwell.

[38] Li-Fen, L. \& Chun-Chieh T. (2013). The influence of leadership behavior and psychological empowerment on job satisfaction. The International Journal of Organizational Innovation, 5 (4), 21-29.

[39] Lunenburg, F. C. (2010). Forces for and resistance to organizational change. National Forum of Educational Administration and Supervision Journal, 27(4), 1-10.

[40] Mabin \& Forgeson (2001) Harnessing resistance: using the theory of constraints to assist change management, Journal of European Industrial Training 25,168-191.

[41] Malik, F., Chugtai, S., Iqbal, Z., \& Muhammad, R.. (2013). Does Psychological Empowerment Bring About Employee Commitment? Evidence From Telecommunication Sector of Pakistan, Journal of Business Studies Quarterly, 5 (5), 14-21.

[42] Mangundjaya, W. H. (2013). Organizational commitment's profile during the transformation and its relation to employee commitment to change. (A study at Oil Company in Indonesia during large-scale organizational change)", Proceedings INBAM Conference, Lisbon, Spain.

[43] Meyer, J. P., \& Allen, N. J. (1991). A three-component conceptualization of organizational commitment. Human Resource Management Review, 1(1), 61-89.

[44] Michaelis, B., Stegmaier, R. \& Sonntag, K. (2010). Shedding light on followers' innovation implementation behavior: the role of transformational leadership, commitment to change, and climate for initiative. Journal of Managerial Psychology, 25 (4), 408-429.

[45] Morgan, D. E., \& Zeffane, R. (2003). Employee involvement, organizational change and trust in management. International Journal of Human Resource Management, 14, 55-75.

[46] Muir, M. M. (2014). How do you create a culture where all employees take accountability for decision making?. Retrieved from Cornell University ILR School, digitalcommons@ilr on January 4th 2017.

[47] Omer, T. \& Umut, K. (2007). Materialistic attitude as an antecedent of organizational citizenship behavior. Management Research News, 30: 581-596.

[48] Oreg, S. (2006). Personality, context, and resistance to organizational change. European Journal of Work and Organizational Psychology, 15(1), 73-101.

[49] Oreg, S. (2003). Resistance to Change: Developing an Individual Difference Measure. Journal of Applied Psychology, $88(4), 680-693$.

[50] Organ, D. W. (1988). Organizational Citizenship Behavior: The Goof soldier Syndrome. Lexington, MA: Lexington Books. 
[51] Organ, D. W.,Podsakoff, P. M., \& MacKenzie S. P. (2006). Organizational citizenship behavior: Its nature, antecedents, and consequences. London: Sage Publications. Organ, D. W. (1988). Organizational Citizenship Behavior: The good soldier.

[52] Pardo del Val, M. And C. M. Fuentez. (2003). Resistance to Change: a Literature Review and Empirical Study. Management Decision. 41, 1-2.

[53] Piderit, S. K. (2000). Rethinking resistance and recognizing ambivalence: A multidimensional view of attitudes toward an organizational change. Academy of Management Review, 25(4), 783-794.

[54] Quinn, R. E., \& Spreitzer, G. M. (1997). The road to empowerment: Seven questions every leader should consider. Organizational Dynamics, 26(2), 37-49.

[55] Rafferty, A. E., \& Simmons, R. H. (2006). An examination of the antecedents of the readiness for fine-tuning and corporate transformation changes", Journal of Business and Psychology, 20 (3), 325-350.

[56] Rahman, A. A. A.,Panatik, S. A. \&Aliasm R. A. (2014). The Influence of Psychological Empowerment on Innovative Work Behavior among Academia in Malaysian Research Universities, International Proceedings of Economics Development and Research, 78(21), 108-112.

[57] Rashid, H. \& Zhao, L. (2010). The significance of career commitment in generating commitment to organizational change among information technology personnel, Academy of Information and Management Sciences Journal, 13(1), 111- 131.

[58] Regar, R. K. Mullane, J. V. Gustafson, L. T. \& DeMarie, S. M. (1994). Creating earthquakes to change organizational mindsets, Academy of Management Executives, 8(4), 31-36.

[59] Robbins, S. P. (2003). Organizational Behavior, Prentice Hall, New Delhi.

[60] Somech, A. \& Drach-Zahavy, A. (2000). Understanding organizational citizenship behavior in schools: The relationships between job satisfactions, sense of efficacy and teachers' extra role behavior. Teaching and Teacher Education, 16, 649-659.

[61] Spreitzer, G. M. (2007). Taking Stock: A review of more than twenty years of research on empowerment at work. In The Handbook of Organizational Behavior, C. Cooper and J. Barling eds. Sage Publications.

[62] Spreitzer, G. M. (1995). Psychological empowerment in the workplace: Dimensions, measurement and validation, Academy of Management Journal, 38, 1442-1465.

[63] Tesluk, P. E., Vance, R. J., \& Mathieu, J. E. (1999). Examining employee involvement in the context of participative work environments. Group and Organization Management, 24, 271-300.

[64] Thompson, J. D. (2011). Organizations in action: Social science bases of administrative theory. New Brunswick, N. J.: Transaction Publishers.

[65] Wanberg, C. R., \& Banas, J. T. (2000). Predictors and outcomes of openness to changes in a reorganizing workplace. Journal of Applied Psychology, 85, 132-142.

[66] Yukl, G. A., \& Becker, W. S. (2006). Effective empowerment in organizations. Organization Management Journal, $3(3), 210-231$. 